\title{
A note on Molluscan diversity and density of some fish ponds of Lalapatti Village Development Committee (VDC), Saptari district, Nepal
}

\author{
Bharat Raj Subba, Prakash Kumar and Shaligram Adhikaree \\ Department ofZoology, Post Gradate Campus, Tribhuvan University, Biratgagar, Nepal \\ E-mail: shaligram_adhikaree@yahoo.com
}

\begin{abstract}
Molluscan diversity of six fish ponds and a river of Lalapatti VDC, Saptari district was studied. In total, ten species of freshwater molluscs belonging to seven families and eight genera were recorded. Among them nine species were found in ponds and five species were recorded in the river samples. Maximum average density was recorded of Bellamya bengalensis $\left(30.38 / \mathrm{m}^{2}\right)$ and minimum for Corbicula alata $\left(0.084 / \mathrm{m}^{2}\right)$
\end{abstract}

Key words: Mollucan diversity, density, fish ponds, Saptari district.

\section{Introduction}

The fish ponds of Lalapatti VDC, Saptari district are man made althou gh they are seen to be too old. Bamboo trees, on the banks and cultivation of makana have made fish ponds unproductive. A perusal of literature concerning with molluscan diversity of Saptari distric reveals that no study has been carried on molluscan diversity yet. However, fragmentary report on molluscs from different parts of Nepal are available, Godwin-Ansten (1910), Subba and Ghosh (2000, 2001, 2008), Subba (2003) Subba and Pandey (2005), Pfeiffer et al. (1999), Subba Rao (1989), Tonapi (1980).

The present paper attempts to give information of molluscan diversity and density of some water bodies of Lalapatti VDC, Saptari. Six fish ponds viz., Shiva pokhari $\left(26^{\circ} 26^{\prime} 48^{\prime \prime} \mathrm{N}, 86^{\circ} 44^{\prime} 48^{\prime \prime} \mathrm{E}\right)$, Lavki pokhari $\left(26^{\circ} 26^{\prime} 49.5^{\prime \prime} \mathrm{N}, 86^{\circ} 44^{\prime} 55^{\prime \prime} \mathrm{E}\right)$, Lali pokhari $\left(26^{\circ} 26^{\prime} 53^{\prime \prime} \mathrm{N}, 8^{\circ} 44^{\prime} 51^{\prime \prime} \mathrm{E}\right)$, Purni pokhari $\left(26^{\circ} 26^{\prime} 43^{\prime \prime} \mathrm{N}, 86^{\circ} 44^{\prime} 48^{\prime \prime} \mathrm{E}\right)$, Buduwahi pokhari $\left(26^{\circ} 26^{\prime} 45^{\prime \prime} \mathrm{N}, 86^{\circ} 44^{\prime} 52^{\prime \prime} \mathrm{E}\right)$, and Budhu pokhari $\left(26^{\circ} 26^{\prime} 43^{\prime \prime} \mathrm{N}, 86^{\circ} 45^{\prime} 02^{\prime \prime} \mathrm{E}\right)$ and a river i.e., Khando river $\left(26^{\circ} 26^{\prime} 54.5^{\prime \prime} \mathrm{N}, 86^{\circ} 45^{\prime} 11.3^{\prime \prime} \mathrm{E}\right)$ were selected for the study.

\section{Mate rials and Methods}

The collection of the mollusc was done randomly in selected sites. Molluscs were collected with the help of a bin sampler. Live molluscs were preserved in 5\% formaldehyde and dry shells were properly washed in clean water using tooth brush, followed by sun drying before packing them in contain ers with cotton so as to prevent breaking. GPS was used to make records of each pond location (and elevation). The collected molluscs were brought to the laboratory of Zoology Department, Post Graduate Campus, Biratnagar. Molluscs samples were identified with the help of standard books of Tonapi (1980), Subba Rao (1989) and Kerney (1999). The identified specimens were counted site-wise, and preserved in separate container safely. 


\section{Results and Discussion}

Ten species of molluscs belonging to seven families and eight genera were recorded. Among them nine species were recorded from the samples of the ponds five species were recorded in the samples collected from the river. Maximum average density was recorded for Bellamya bengalensis $\left(30.38 / \mathrm{m}^{2}\right)$ and minimum for Corbicula alata $\left(0.084 / \mathrm{m}^{2}\right)($ Table 1$)$. The population of the collected molluscs was estimated and found that the macrophyte rich fish ponds contained more density than those having fewer amounts of macrophyte and unsuitable substrates like mud and sand. As this report imparts information of only winter season (2011), for detailed information further study is recommended.

Table 1. Estimated mean density $\left(\right.$ per $\mathrm{m}^{2}$ ) of molluscs (mean \pm standard error). - indicates absence of species of molluscs in the sites.

\begin{tabular}{|c|c|c|c|c|c|c|c|c|}
\hline \multirow{2}{*}{ Molluscs } & \multicolumn{8}{|c|}{ Locality } \\
\hline & Budhu & Khando & Lali & Budhuahi & Shiva & Lavaki & Pu rni & Average \\
\hline$\overline{\text { Bellamya }}$ & 22.55 & & 42.19 & 22.01 & 20.01 & 46.1 & 23.32 & 30.38 \\
\hline bengalensis & \pm 1.795 & - & \pm 1.96 & \pm 1.48 & \pm 1.35 & \pm 2.05 & \pm 1.71 & \pm 0.73 \\
\hline Indoplanorbis & 0.68 & & & 83.24 & 83.94 & 3.91 & 13.75 & 31.98 \\
\hline exurtus & \pm 0.31 & - & - & \pm 2.89 & \pm 2.76 & \pm 0.60 & \pm 1.31 & \pm 0.75 \\
\hline Lymnaea sp. & - & - & - & $\begin{array}{c}0.48 \\
\pm 0.22\end{array}$ & $\begin{array}{c}0.43 \\
\pm 0.20\end{array}$ & NO & - & $\begin{array}{c}0.17 \\
\pm 0.05\end{array}$ \\
\hline Pila globosa & $\begin{array}{c}0.68 \\
\pm 0.31\end{array}$ & - & - & $\begin{array}{c}0.96 \\
\pm 0.31\end{array}$ & $\begin{array}{c}0.87 \\
\pm 0.28\end{array}$ & $\begin{array}{c}0.87 \\
\pm 0.28\end{array}$ & - & $\begin{array}{c}0.59 \\
\pm 0.10\end{array}$ \\
\hline Parreysia sp. & $\begin{array}{c}6.83 \\
\pm 0.99\end{array}$ & $\begin{array}{l}114.82 \\
\pm 10.72\end{array}$ & - & - & - & $\begin{array}{c}0.87 \\
\pm 0.28\end{array}$ & - & $\begin{array}{c}3.02 \\
\pm 0.23\end{array}$ \\
\hline P. flaviden & $\begin{array}{r}1.37 \\
\pm 0.44 \\
\end{array}$ & $\begin{array}{l}52.62 \\
\pm 7.25 \\
\end{array}$ & - & - & - & - & - & $\begin{array}{c}1.09 \\
\pm 0.14 \\
\end{array}$ \\
\hline Thiara scruba & $\begin{array}{l}17.09 \\
\pm 1.56\end{array}$ & $\begin{array}{r}133.95 \\
\pm 11.57\end{array}$ & - & - & - & - & - & $\begin{array}{c}4.45 \\
\pm 0.28\end{array}$ \\
\hline T. tuberculata & $\begin{array}{c}2.73 \\
\pm 0.62\end{array}$ & $\begin{array}{l}38.27 \\
\pm 6.19\end{array}$ & - & - & - & - & - & $\begin{array}{c}1.01 \\
\pm 0.13\end{array}$ \\
\hline $\begin{array}{l}\text { Corbicula } \\
\text { alata }\end{array}$ & $\begin{array}{c}0.68 \\
\pm 0.31\end{array}$ & - & - & - & - & - & - & $\begin{array}{c}0.08 \\
\pm 0.04\end{array}$ \\
\hline $\begin{array}{l}\text { Lammelidens } \\
\text { marginalis }\end{array}$ & - & $\begin{array}{c}4.78 \\
\pm 2.19\end{array}$ & - & - & - & - & - & $\begin{array}{l}0.084 \\
\pm 0.04\end{array}$ \\
\hline Total molluscs & $\begin{array}{l}52.62 \\
\pm 2.74\end{array}$ & $\begin{array}{l}344.45 \\
\pm 18.56\end{array}$ & $\begin{array}{l}42.19 \\
\pm 1.96\end{array}$ & $\begin{array}{c}106.68 \\
\pm 3.27\end{array}$ & $\begin{array}{l}105.25 \\
\pm 3.09\end{array}$ & $\begin{array}{l}51.75 \\
\pm 2.17\end{array}$ & $\begin{array}{l}30.01 \\
\pm 1.94\end{array}$ & $\begin{array}{l}72.85 \\
\pm 1.13\end{array}$ \\
\hline
\end{tabular}

\section{Acknowledgements}

We would like to express our sincere thanks to the owners of fish ponds who extended their co-operation during field work.

\section{References}

Godwin-austen, H.H. 1990. Land and freswater Mollusca of India including South Arabia, Baluchistan, Afghanistan, Kashmir, Nepal, Burma, Pegu, Tensserim, Maly Peninsula, Ceylon and other islands of the Indian Ocean. Suppl. to the Obald \& Hanley's Conchologia Indica, London.

Kerney, M. 1999. Atlas of the land and freshwater molluscs of Britain and Ireland. Harley Books 
Pfeiffer, M., S. Sharma \& B.M. Dahal. 1999. Age and population structure of freshwater Mussel in the lowland rivers of Nepal. Proc. of III Nat. Conf. on Sci. \& Tech. pp. 1371-1377.

Preston, H.B. 1915. The fauna of British Indian including Ceylon and Burma. Mollusca (freshwater Gastropoda and pelecypoda). Tay lor \& Francis, London. 224p.

Subba Rao, N.V. 1989. Handbook of freshwater mollusks of India. Publ. Zoological Survey of India, Calcutta.

Subba, B.R. \& R. Pandey. 2002. Molluscan diversity of Jhapa district. A report to Royal Nepal Academy of Science \& Technology, Kathmandu, Nepal.

Subba, B.R. \& T.K. Ghosh. 2000. Some freshwater mollusks from eastern and central Nepal. J. Bomb. Nat. His. Soc. 97(3): 452-455.

Tonapi, G.T. 1980. Freshwater animals of India (An ecological approach). Oxford \& IBH Publ. Co., New Delhi. 